\title{
"Ceria"
}

Jurnal Program Studi Pendidikan Anak Usia Dini

ISSN 2301-9905

Volume 7, No. 2, Januari 2018

Fakultas Keguruan dan Ilmu Pendidikan - Universitas Muhammadiyah Tangerang

\section{Dampak Perceraian Orangtua Terhadap Kemampuan Berbicara Pada Anak Usia 6 Tahun}

\author{
Siti Khodijah ${ }^{1}$, Nurul Fitria Kumala Dewi ${ }^{2}$ \\ 1,2Program Studi Pendidikan Guru Pendidikan Anak Usia Dini; Fakultas \\ Keguruan dan Ilmu Pendidikan; Universitas Muhammadiyah Tangerang \\ Email : ${ }^{1}$ khadijah.arrozi@gmail.com, ${ }^{2}$ nurulfiriakd@gmail.com
}

\begin{abstract}
Abstrak
Penelitian ini bertujuan untuk mengetahui dampak perceraian orangtua terhadap kemampuan berbicara anak usia 6 tahun. Kemampuan berbicara bukan hanya sekedar pengucapan kata atau bunyi, tetapi merupakan suatu keterampilan berbahasa yang berkembang. Kemampuan berbicara anak usia 5-6 tahun adalah anak sudah menguasai kosakata 1500 kosakata atau lebih, mengucapkan kalimat lima sampai tujuh kata, mengucapkan kalimat-kalimat yang hampir dapat dimengerti secara keseluruhan, dapat bercakap-cakap seperti orang dewasa, menggunakan bentuk kata kerja dan urutan kata serta struktur kalimat yang tepat. Akan tetapi pada sumber data yang peneliti dapatkan kemampuan berbicaranya rendah, anak belum dapat mengucapkan beberapa kata dengan jelas dan pola komunikasi yang digunakan cenderung diam dan pasif. Penelitian ini termasuk jenis penelitian kualitatif deskriptif yang mengacu kepada hasil observasi dan wawancara. Pada penelitian ini ditemukan dua sumber data yaitu $\mathrm{VH}$ dan ES. Teknik pengumpulan data dilakukan dengan menggunakan catatan wawancara dan catatan observasi. Penelitian ini juga didukung oleh dokumentasi yang memadai. Hasil data disajikan secara narasi deskriptif. Hasil penelitian menunjukkan bahwa perceraian orangtua berdampak pada kemampuan berbicara anak usia 6 tahun. Berdasarkan hasil temuan penelitian yang didapatkan, maka penelitian ini layak digunakan oleh masyarakat luas dan dapat dikembangkan untuk penelitian yang lebih lanjut.
\end{abstract}

Kata kunci : Perceraian Orangtua, Kemampuan Berbicara, Anak Usia 6 Tahun

\section{Pengantar}

Perkembangan merupakan hal yang terjadi pada setiap individu, menurut Chaplin dalam Desmita, (2002, h. 4) mengartikan perkembangan sebagai perubahan yang berkesinambungan dan progresif dalam organisme, dari 
lahir sampai mati, pertumbuhan, perubahan dalam bentuk dan dalam integrasi dari bagian-bagian jasmaniah ke dalam bagian-bagian fungsional, kedewasaan atau kemunculan pola-pola asasi dari tingkah laku yang tidak dipelajari. Aspekaspek perkembangan yang terjadi pada anak usia dini meliputi : aspek fisik dan motorik, aspek kognitif, aspek bahasa, aspek moral dan nilai-nilai agama, aspek sosio-emosional, aspek seni dan kreativitas.

Salah satu aspek yang penting dalam perkembangan anak adalah perkembangan bahasa dimana perkembangan bahasa ini berkaitan dengan perkembangan lainnya. Menurut Hapsari (2016, h. 151) bahasa merupakan sistem komunikasi yang didasarkan pada kata dan bahasa. Dengan bahasa anak dapat mengeksplor kehidupannya, sedangkan keterkaitan antara bahasa dengan perkembangan lainnya dapat ditinjau dari cara anak bersosialisasi dengan lingkungannya, anak yang perkembangan bahasanya rendah cenderung lebih pasif dan pendiam dalam melakukan kegiatan.

Menurut Jamaris dalam Susanto (2011, h.78) perkembangan bahasa anak usia 5-6 tahun sudah dapat mengucapkan lebih dari 2.500 kosakata, lingkup kosakata yang dapat diucapkan anak menyangkut warna, ukuran, bentuk, rasa, bau, keindahan, kecepatan, suhu, perbedaan, perbandingan, jarak, dan permukaan (kasar-halus), anak usia 5-6 tahun sudah dapat berpartisipasi dalam suatu percakapan. Anak sudah dapat mendengarkan orang lain berbicara dan menanggapi pembicaraan tersebut. Percakapan yang dilakukan oleh anak 5-6 tahun telah menyangkut berbagai komentarnya terhadap apa yang dilakukan oleh dirinya sendiri dan orang lain, serta apa yang dilihatnya. Menurut Allen dan Marotz (2010, h.151) karakteristik perkembangan kemampuan berbicara anak usia 5-6 tahun adalah anak sudah menguasai kosa kata 1500 kosa kata atau lebih, mengucapkan kalimat lima sampai tujuh kata, mengucapkan kalimatkalimat yang hampir dapat dimengerti secara keseluruhan, dapat bercakapcakap seperti orang dewasa, menggunakan bentuk kata kerja dan urutan kata serta struktur kalimat yang tepat. 
Namun pada kenyataanya berdasarkan observasi (oktober, 2016) di TK Nurul Irfan terdapat seorang anak berusia 6 tahun yang bernama VH cenderung diam dan kurang berkomunikasi kepada teman atau pun gurunya, begitu pula saat berkomunikasi vokal bahasanya belum jelas serta belum mampu menggunakan tata bahasa yang akurat, seperti dalam suatu komunikasi $\mathrm{VH}$ bercerita bahwa dirinya baru saja sembuh dari sakit, VH bercerita "Bu guru aku anas using minum obat sembuh". Kalimat yang seharusnya diucapkan "Bu guru aku sakit panas dan pusing aku sudah sembuh setelah minum obat". Berdasarkan percakapan $\mathrm{VH}$ tersebut dapat dilihat bahwa dalam pengucapan bahasa vokalnya belum jelas seperti kata "Panas" menjadi "Anas".

Berdasarkan beberapa kegiatan yang peneliti pernah amati $\mathrm{VH}$ cenderung mengulang kata-kata yang diucapkan temannya, hal ini seperti saat salah seorang temannya bernama ND bercakap "bu guru aku rapihin ya mejanya", dan VH pun mengulang kata yang sama "bu guru rapihin" dengan maksud yang sama $\mathrm{VH}$ mengulang kata itu meski belum sesuai dengan yang diucapkan temannya. Pada awalnya peneliti merasa kejadian tersebut wajar terjadi, akan tetapi seiring berjalannya waktu $\mathrm{VH}$ akan mengulang beberapa kata yang diucapkan temannya, yang menurut $\mathrm{VH}$ itu kata-kata baru yang didapatkan.

Pada saat evaluasi anak diminta untuk menceritakan pengalamannya usai kegiatan renang, semua anak satu persatu maju kedepan kelas dan mulai bercerita apa saja yang dilakukan saat kegiatan renang dan apa yang mereka rasakan. Semua anak terlihat antusias, akan tetapi pada saat VH mendapat giliran bercerita didepan kelas dia hanya diam dan guru membantu melalui beberapa pertanyaan danVH pun hanya menjawab pertanyaan saja. Berdasarkan hal tersebut seharusnya $\mathrm{VH}$ sudah dapat mengutarakan komentar dan perasaannya kedalam percakapan tersebut.

Berdasarkan hal tersebut peneliti mencoba meneliti hal apa yang mendasari kemampuan berbicara $\mathrm{VH}$ rendah dibandingkan dengan teman- 
teman sebayanya. Menurut beberapa informasi yang peneliti dapatkan VH merupakan anak dari keluarga yang orangtuanya sudah bercerai dan sang ibu yang berkerja berperan mengantikan tugas sang ayah, dan $\mathrm{VH}$ sehari-hari hanya dengan sang nenek. Peneliti menyadari ada beberapa faktor yang dapat mempengaruhi perkembangan bahasa anak usia 6 tahun. Syamsu (2016, h.121) mengatakan bahwa perkembangan bahasa dipengaruhi oleh 5 faktor, yaitu: faktor kesehatan, intelegensi, status sosial ekonomi, jenis kelamin, dan hubungan keluarga. Berdasarkan 5 faktor tersebut dapat dilihat bahwa hubungan keluarga dapat mempengaruhi perkembangan bahasa anak karena keluarga merupakan lembaga sosial yang paling awal dikenal dan dekat dengan anak.

Narwoko dan Suyanto, (2004, h.84) keluarga adalah lembaga sosial dasar darimana semua lembaga atau pranata sosial lainnya berkembang. Dalam masyarakat di dunia, keluarga merupakan kebutuhan manusia yang universal dan menjadi pusat terpenting dari kegiatan dalam kehidupan individu. Perkembangan bahasa pada anak tidak lepas dari peranan keluarga. Anak pertama kali belajar segala sesuatu di lingkungan keluarga dan orang tua adalah guru pertama bagi anak dalam mengembangkan kemampuan bahasanya.

Hal ini membuat orang tua memiliki andil besar dalam pendidikan anaknya, baik dalam segi waktu, materi, dan tenaga. Penyediaan sarana dan prasarana pendidikan di lingkungan rumah merupakan hal penting bagi proses perkembangan anak. Hal terpenting dalam perkembangan bahasa anak adalah bagaimana orang tua membuat kondisi rumah sedemikian rupa agar mampu menghasilkan stimulus positif sebanyak dan sevariatif mungkin. Sesuai dengan nalurinya, anak senantiasa ingin mengetahui segala hal dan mencoba sesuatu yang baru. Pemberian stimulus akan mempengaruhi perubahan perilaku anak. Stimulus yang diberikan orang tua akan terbingkai dalam pola pikir, pola tindak, dan pola ucap anak.

Oleh karena itu dibutuhkan kerjasama antar ibu dan ayah untuk dapat memberikan stimulus yang tepat agar perkembangan bahasa anak dapat 
berkembangan tepat dan sesuai dengan tahapan perkembangannya. Anak membutuhkan kedua orangtuanya untuk selalu mendukung dan menstimulus semua perkembangannya, karena kehidupan kelak dimasa mendatang dipengaruhi pada usia dini anak.

\section{Metode}

Berdasarkan jenis data yang diperlukan dalam penelitian ini, maka penulis menggunakan metode kualitatif. Artinya, data yang dikumpulkan bukan berupa angka-angka, melainkan data tersebut berasal dari naskah wawancara, catatan laporan, dokumen pribadi, catatan memo dan dokumen lainnya. Menurut Sugiyono (2016, h. 9) metode kualitatif adalah metode penelitian yang berlandaskan pada filsafat postpotivisme, yang digunakan untuk meneliti pada kondisi obyek yang alamih. Dijelaskan juga bahwa penelitian kualitatif menurut Bogdan dan Taylor dalam Moleong (2014, h. 4) metode kualitatif sebagai prosedur penelitian yang menghasilkan data deskriptif berupa ata-kata tertulis atau lisan dari orang-orang dan perilaku yang dapat diamati.

Pemilihan jenis penelitian kualitatif ini dikarenakan peneliti menganggap bahwa penelitan akan maksimal untuk mengetahui dampak dari perceraian orang tua terhadap kemampuan berbicara pada anak usia 6 tahun. Dalam hal ini, penelitian dilakukan lebih spesifik, yaitu untuk meneliti dampak dari perceraian yang terjadi sehingga membuat kemampuan berbicara anak usia 6 tahun berkurang.

Dalam hal ini, peneliti menggunakan jenis metode pendekatan yang digunakan dalam penelitian ini adalah pendekatan studi kasus (Case Study). Menurut Arikunto (2013, h. 115) studi kasus yaitu suatu penelitian yang dilakukan secara intensif, terinci dan mendalam terhadap suatu organisasi, lembaga atau gejala tertentu. Sedangkan menurut Nasution $(2012$, h. 30) studi kasus adalah bentuk penelitian yang mendalam tentang suatu aspek lingkungan sosial termasuk manusia didalamnya. Studi kasus dapat dilakukan terhadap 
seorang individu, sekelompok individu, maupun segolongan individu. Selanjutnya menurut Yin dalam Tohirin, (2012, h. 20) penelitian kualitatif studi kasus digunakan untuk mengetahui dengan lebih mendalam dan terperinci tentang suatu permasalahan atau fenomena yang hendak diteliti.

Penelitian studi kasus tersebut merupakan suatu penelitian yang dilakukan secara intensif, terinci dan mendalam. Dalam penelitian studi kasus ini peneliti menggunakan jenis studi kasus tunggal, seperti yang dijelaskan dalam Tohirin, (2012, h. 22) studi kasus ada dua jenis, yaitu studi kasus tunggal dan studi kasus majemuk (studi kasus kolektif).

Dalam hal ini peneliti menggunakan studi kasus tunggal, dimaksudkan agar penelitian dapat lebih spesifik dan mendalam. Penelitan studi kasus tunggal ini peneliti hanya meneliti satu orang subjek yaitu $\mathrm{VH}$ anak usia 6 tahun yang kemampuan berbicaranya rendah, dan meneliti satu fenomena saja yaitu dampak dari perceraian orang tuanya.

Peneliti bertujuan untuk menggali dan mencari tahu mengapa kemampuan berbicara $\mathrm{VH}$ rendah, bagaimana kemampuan berbicara $\mathrm{VH}$ sebelum perceraian tersebut terjadi, dan sesudah perceraian. Selain itu, peneliti melakukan wawancara dan analisis langsung terhadap kemampuan berbicara VH dalam kegiatan kesehariannya.

\section{Hasil Dan Pembahasan}

Berdasarkan temuan penelitian mengenai dampak penceraian orangtua terhadap kemampuan berbicara anak usia 6 tahun, peneliti akan berusaha menyajikan secara bertahap. Pertama memaparkan tentang kemampuan berbicara anak sebelum perceraian, kedua kemampuan berbicara anak sesudah perceraian, dan yang ketiga gaya bahasa yang digunakan oleh anak yang orangtuanya bercerai.

Dalam penelitian ini telah ditemukan bagaimana kemampuan berbicara anak sebelum perceraian. Berdasarkan penelitian yang dilakukan peneliti telah 
mewawancara beberapa sumber data, sumber data yang pertama adalah anak usia 6 tahun bernama $\mathrm{VH}$ yang orang tuanya bercerai dan kini tinggal bersama ibu serta neneknya. Sumber data yang kedua adalah ES anak usia 6 tahun yang orangtuanya bercerai dan kini tinggal bersama ayah dan neneknya.

Pada sumber data yang pertama peneliti melakukan wawancara dengan ibu dan nenek VH untuk mendapatkan informasi mengenai bagaimana kemampuan berbicara VH sebelum perceraian. Pada wawancara dengan mama dan nenek VH didapatkan bahwa kemampuan berbicara $\mathrm{VH}$ sebelum perceraian sudah rendah (CWS I.1:23 h. 78). Pada saat VH berusia 2-3 tahun orangtua VH masih bersama, saat usia tersebut anak-anak sebayanya sudah mulai aktif untuk menyebutkan beberapa kata baru dan meniru kata yang didengarnya, akan tetapi berbeda dengan $\mathrm{VH}$, saat usia tersebut $\mathrm{VH}$ cenderung sering menangis dan lebih sering berkomunikasi menggunakan gesture tubuh (CW S II. 2:32 h. 93).

Selain hal itu VH juga jarang diajak bersosialisasi dengan lingkungan sekitarnya, dikarenakan ayahnya yang pemalu dan jarang bersosialisasi dengan lingkungan sekitarnya, sehingga cenderung hanya dirumah saja dan hanya diberikan mainan-mainan yang membuatnya tenang dan tidak menangis (CWS I.1:41 h. 79). Ayah VH yang pola komunikasinya pendiam jarang mengajak $\mathrm{VH}$ berkomunikasi, sehingga pada saat $\mathrm{VH}$ berusia 2-3 tahun orangtuanya kurang memperhatikan kemampuan berbicaranya, dan jarang sekali mendengar $\mathrm{VH}$ berbicara atau meniru suara, $\mathrm{VH}$ hanya aktif menangis dan asik bermain dengan mainan kesukaannya (CWS II.1:42 h.82 ).

Pada sumber data yang kedua bernama ES peneliti mendapatkan hasil temuan bahwa kemampuan berbicara ES dapat dikategorikan cukup berkembang pada saat keuda orangtuanya masih bersama dan ES masih dibawah asuhan ibunya. Hal ini diketahui setelah melakukan wawancara dengan ayah dan nenek ES.

Pada wawancara dengan ayah dan nenek ES mengenai bagaimana kemampuan berbicara ES sebelum perceraian peneliti mendapatkan, bahwa 
pada saat ES berusia 3-4 tahun dan orangtua ES belum bercerai, ia cenderung aktif berkomunikasi seperti senang bercerita dengan ibunya serta sering mengucapkan berbagai kalimat (CWS III.3:8 h. 99). Selain itu ES juga gemar terhadap buku-buku bacaan, meskipun ES jarang berinteraksi dengan lingkungan sekitarnya, akan tetapi ibu ES aktif dalam memberikan stimulasi baik yang mendukung perkembangan berbicara maupun perkembangan kognitif (CWS IV.2:23 h. 98).

Ayah ES yang bekerja sangat jarang meluangkan waktu untuk memperhatikan kemampuan dan perkembangan ES, semua tugas tersebut dilimpahkan kepada ibu ES yang memang sehari-hari menjadi ibu rumah tangga. Ibu ES melimpahkan setiap waktunya untuk menjaga dan medidik ES, sehingga saat usia tersebut ES anak yang periang dan penurut (CWS IV.3:7 h. 101).

Berdasarkan hal tersebut dapat diketahui bahwa kemampuan berbicara sumber data ES pada saat sebelum perceraian dapat dikatagorikan cukup baik. Akan tetapi pada sumber data yang pertama terbilang rendah bahkan pada saat sebelum percerian. Pada hal tersebut maka dapat diketahui bahwa penyebab rendahnya kemampuan berbicara dapat dipengaruhi pada beberapa faktor seperti faktor keturunan/genetik serta faktor keluarga. Untuk dapat meningkatkan kemampuan berbicara anak harus mendapatkan stimulasi yang baik dan benar. Selain itu peran orangtua juga menjadi sangat penting dalam meningkatkan kemampuan berbicara anak.

Setelah mendapatkan temuan penelitian mengenai kemampuan berbicara anak sebelum perceraian peneliti juga mendapatkan temuan penelitian mengenai kemampuan berbicara sesudah perceraian. Berdasarkan hasil observasi yang dilakukan peneliti pada bulan April dan Juli 2017 terhadap sumber data, peneliti menemukan berbagai temuan penelitian mengenai kemampuan berbicara sumber data sesudah perceraian. Pada observasi yang dilakukan peneliti kemampuan berbicara $\mathrm{VH}$ dapat dikategorikan rendah. Hal itu ditunjukan dengan pola komunikasi $\mathrm{VH}$ yang cenderung diam dan jarang melakukan 
interaksi. Seperti saat kegiatan berdoa $\mathrm{VH}$ belum dapat mengucapkan secara jelas dan membutuhkan usaha lebih untuk melafalkanya (CO I.1:4 h. 104). Begitu pula saat bersama teman-temanya pun $\mathrm{VH}$ cenderung meniru apa yang diucapkan oleh temannya(CO I.2:3-6 h. 107).

Saat proses belajar mengajar $\mathrm{VH}$ bisa mengikuti dengan baik jika yang berlangsung adalah kegiatan kognitif seperti berhitung, $\mathrm{VH}$ sudah dapat menyebutkan bilangan angka 1-10 dengan berurutan, dapat menghitung jumlah benda secara teratur, dan mampu mengurutkan angka 1-10. Pada kegiatan meniru tulisan $\mathrm{VH}$ juga sudah mampu meniru bentuk geometri seperti segitiga, persegi empat, dan lingkaran. Bahkan $\mathrm{VH}$ sudah mampu meniru huruf $\mathrm{A}-\mathrm{Z}$ secara teratur dan berurutan (CO I.2:24 h. 108). Namun pada saat kegiatan bahasa seperti bercerita $\mathrm{VH}$ lebih cenderung diam, berlari-lari atau bercanda dengan temanya sehingga guru harus mengarahkan $\mathrm{VH}$ untuk dapat berdiri didepan kelas untuk bercerita dan guru harus mengajukan berbagai pertanyaan untuk memancing $\mathrm{VH}$ bercerita. Begitu pula dalam kegiatan membaca $\mathrm{VH}$ cenderung tidak mengikuti, $\mathrm{VH}$ akan meminta temannya untuk membaca terlebih dahulu dan $\mathrm{VH}$ sibuk dengan kegiatannya sendiri seperti membongkarbongkar isi tasnya. Sehingga dalam hal ini guru harus merayu VH untuk mau membaca (CO I.3:13-16 h. 112).

Pada sumber data yang kedua bernama ES peneliti melakukan observasi selama bulan Juli 2017. Peneliti mendapatkan hasil temuan bahwa ES belum mampu mengucapkan beberapa huruf vocal dengan baik dan benar. Seperti pada saat kegiatan rutin yang dilakukan sekolah yaitu solat dhuha bersama (CO II.1:5 h. 106). Selain itu bahkan ES belum mampu mengikuti berbagai kegiatan baik kegiatan yang menstimulasi kognitif seperti kegiatan meniru tulisan ES bahkan belum mampu memegang alat tulis dengan baik, serta belum mampu membuat coretan secara terarah (CO II. 3:20 h. 114).

Berdasarkan hal tersebut dapat diketahui bahwa kemampuan berbicara dari sumber data masih rendah, penyebab rendahnya kemampuan berbicara 
dapat dipengaruhi pada beberapa faktor. Untuk dapat meningkatkan kemampuan berbicara anak harus mendapatkan stimulasi yang baik dan benar. Selain itu peran orangtua juga menjadi sangat penting dalam meningkatkan kemampuan berbicara anak. Seperti yang terjadi pada VH saat ibu dan neneknya sadar bahwa kemampuan berbicara $\mathrm{VH}$ yang rendah mereka berusaha menstimulasi dan memberikan perhatian yang cukup. Akan tetapi hal ini tidak terjadi pada ayah ES, ditemukan bahwa terdapat ketidak sesuaian dalam pembicaraan yang dilakukan oleh ayah ES, dalam pembicaraan tersebut ayah ES mengungkapkan bahwa menurutnya kemampuan berbicara ES tidak bermasalah, akan tatapi dilanjutkan dengan keterangan bahwa ia kurang memperhatikan ES. Sehingga dapat diketahui bahwa ayah ES tidak memahami dan kurang memberikan perhatian terhadap ES, sehingga tidak ada usaha lebih untuk meningkatkan kemampuan berbicara ES.

Anak yang berasal dari keluarga yang orangtuanya bercerai biasanya selain kemampuan berbicaranya yang rendah juga bahasa yang digunakan cenderung lebih kasar, karena kurang terkontrolnya bahasa yang anak dapatkan dari lingkungan sekitarnya. Hal ini juga peneliti dapatkan pada sumber data yang peneliti amati. Pada sumber data yang pertama yaitu $\mathrm{VH}$, bahasa yang digunakan cenderung tidak terlalu berbeda dengan anak-anak sebayanya, hanya saja VH yang pola komunikasinya cenderung pasif jarang mengungkapkan bahasa seperti mengekspresikan ide gagasan dan menjawab pertanyaan yang lebih kompleks (CO I. 2:8 h. 108). Bahasa yang digunakan VH juga cenderung lebih kasar dikarenakan $\mathrm{VH}$ yang sering meniru apa yang didengarnya dan $\mathrm{VH}$ juga belum mampu untuk mengetahui apakah itu bahasa yang baik atau bahasa yang kotor (CO I. 2:18 h. 108).

Sedangkan pada sumber data yang kedua yaitu ES, bahasa yang digunakan cenderung lebih kasar dan kotor, ES yang setiap harinya berada dilingkungan main yang kurang terkontrol baik oleh ayah maupun neneknya menjadikan ES meniru semua bahasa yang didapatkannya termasuk bahasa 
yang kasar dari lingkungan sekitarnya (CO II.2:7 h. 110). Selain itu akibat perceraian orangtua tersebut ES menjadi anak yang kurang mau mendengarkan apa yang disampaikan orang lain (CO II.3:15 h. 114),

Dampak perceraian orang tua dapat menjadi sangat besar terhadap kemampuan berbiara anak, karena pada saat anak kurang mendapatkan kasih sayang dan perhatian dari yang seharusnya diberikan oleh kedua orang tuanya, maka anak biasanya akan mencari sendiri dan mempelajari dari hal-hal yang membuatnya merasa aman dan nyaman. Sehingga terkadang bahasa yang digunakan oleh anak yang orangtuanya bercerai cenderung kasar, hal ini terjadi karena tidak adanya perhatian yang intens terhadap apa yang didapat anak dari lingkungannya.

\section{Kesimpulan}

Berdasarkan hasil penelitian kualitatif dengan dengan teknik observasi, wawancara dan dokumentasi tentang dampak perceraian orangtua terhadap kemampuan berbicara anak usia 6 tahun dapat diambil beberapa kesimpulan, antara lain kemampuan berbicara anak sebelum perceraian terbilang cenderung beragam, pada penelitian pada sumber data yang peneliti dapatkan terdapat perbedaan yang cukup bervariasi, pada sumber data yang pertama kemampuan berbicaranya sudah cenderung rendah bahkan pada saat kedua orangtuanya belum bercerai. Pada usia 2-3 tahun saat orangtua $\mathrm{VH}$ belum bercerai kemampuan berbicara $\mathrm{VH}$ sudah cenderung rendah dikarenakan komunikasi yang pasif serta jarangnya sosialisasi dengan lingkungan serta peran ayah yang cenderung jarang mengajak $\mathrm{VH}$ bersosialisasi serta riwayat sang ayah yang diketahui pernah mengalami kemampuan berbicara yang rendah sejak usia 2 tahun hingga usia 12 tahun.

Sedangkan pada sumber data yang kedua kemampuan berbicaranya cenderung aktif dan sering berkomunikasi dengan sang ibu yang sering memberikan stimulasi-stimulasi yang baik untuk meningkatkan kemampuan berbicara ES, pada saat orangtuanya belum bercerai ES sangat dekat dengan sang 
ibu dan lebih banyak mengahabiskan waktu dengan ibu, selain itu ES terbilang periang dan ceria.

Kemampuan berbicara anak sesudah perceraian, perceraian orangtua dapat memberikan dampak yang besar bagi anak terutama bagi kemampuan berbicaranya, bahwa perceraian orangtua dapat membuat anak merasakan kurangnya perhatian dan kasih sayang, serta pengawasan orangtua terhadap kemampuan yang dimiliki anaknya itu akan sangat berpengaruh untuk memberikan stimulasi-stimulasi yang baik dan tepat agar meningkatkan kemampuan berbicara anak. Pada sumber data yang pertama yaitu VH kemmapuan berbicara sesudah perceraian tidak banyak perubahan yang signifikan dikarenakan kemampuan berbicara $\mathrm{VH}$ sudah rendah sejak kedua orangtuanya belum bercerai dan hal tersebut didasari oleh faktor bawaan/genetik yang diturunkan dari sang ayah.

Sedangkan pada sumber data yang kedua terdapat perbedaan yang sangat signifikan dikarenakan kemampuan berbicaranya sudah jauh lebih berkembang pada saat orangtuanya belum bercerai hal tersebut didasarkan faktor keluarga atau faktor kasih sayang yang diberikan oleh orangtua, sehingga pada saat orangtuanya bercerai menjadikan anak merasa kehilangan serta kekurangan kasih sayang.

Bahasa yang digunakan anak yang orangtuanya bercerai, perceraian biasanya akan sangat berdampak bagi kemampuan berbicara anak, anak biasanya akan menunjukkan berbagai macam reaksi, seperti menjadi pemarah ataupun pendiam. Selain itu biasanya bahasa yang digunakan oleh anak yang orangtuanya bercerai cenderung menggunakan bahasa yang kasar dan kotor, hal tersebut biasanya didasari dari bahasa-bahasa yang diterima anak dari lingkungan sekitarnya serta kurangnya pengawasan dari orangtua sehingga anak belum mampu memilih bahasa yang baik digunakan dan kurang baik untuk digunakan. 
Berdasarkan kesimpulan di atas, ada beberapa hal penting yang dapat ditindak lanjut yaitu 1) Peranan orangtua sangat dominan dalam meningkatkan kemampuan berbicara pada anak usia 6 tahun. Orangtua dapat memberi teladan yang baik dilingkungan keluarga, lingkungan sekolah maupun lingkungan masyarakat. 2) Bagi orangtua yang bercerai harap kiranya memperhatikan faktor - faktor lain untuk meningkatkan kemampuan berbicara pada anak seperti memberi kasih sayang dan perhatian yang seutuhnya. Sehingga anak tidak merasa akan kurangnya perhatian dan kasih sayang dari orangtuanya.

\section{Daftar Acuan}

Arikunto, Suharsini. (2013). Prosedur Penelitian Suatu Pendekatan Praktik. Jakarta. Rineka Cipta.

Aziz, Safrudin. (2015). Pendidikan Keluarga Konsep dan Strategi. Yogyakarta. Gava Media.

Desmita (2009). Psikologi Perkembangan Peserta Didik. Bandung. PT Remaja Rosda Karya

Dhieni, Nurbiana, dkk. (2007). Metode pengembangan bahasa. Jakarta. Pusat Penerbitan Universitas Terbuka.

Lestari, Sri (2012). Psikologi Keluarga. Jakarta. Prenada Media Group

Moleong, Lexy J. (2014).Metodologi Penelitian Kualitatif. Jakarta. Rosada Karya

Syaifuddin, Turatmiyah, dkk. (2014). Hukum Perceraian. Jakarta. Sinar Grafika

Syamsu, Yusuf (2016) Psikologi Perkembanga nAnak dan Remaja. Jakarta. Rosda

Tiel, Julia Maria Van. (2011). Pendidikan Anakku Terlambat Berbicara. Jakarta. Prenada Media

Tohirin.(2012). Metode Penelitian Kualitatif dalam Pendidikan dan Bimbingan Konseling. Jakarta. Rajawali Press 